\title{
PERBEDAAN PENGARUH KOMPETENSI PEDAGOGIK GURU TERHADAP KEMAMPUAN BERPIKIR KRITIS SISWA PADA PEMBELAJARAN MATEMATIKA TENTANG VOLUME BANGUN RUANG DI KELAS V SD NEGERI SEKECAMATAN ALIAN TAHUN AJARAN 2020/2021
}

\author{
Nashri Maulidah ${ }^{1}$, Rokhmaniyah $^{2}$, Suhartono $^{3}$ \\ Universitas Sebelas Maret \\ nashrimaulidah57@gmail.com
}

\section{Article History}

accepted 1/11/2021

\begin{abstract}
The study aimed to analyze the difference between high teacher's pedagogical competence and low teacher's pedagogical competence on student's critical thinking ability in mathematics about volume of solid figures in fifth grade public elementary schools at Alian Sub-district in academic year of 2020/2021. The research was a quantitative approach with comparative research method. The population were 35 teachers and 847 students. The samples were 17 teachers and 162 fifth grade students of public elementary schools in Alian Sub-district. Data collection technique used test. The data analysis used independent sample t-test. The result showed that there were differences between student's critical thinking ability taught by high teacher's pedagogical competence and low teacher's pedagogical competence. The average of student's critical thinking ability taught by high teacher's pedagogical competence was 68.49 and the average of student's critical thinking ability taught by low teacher's pedagogical competence was 58.90. It indicated that the Sig. value was $0.000<0.05$ and $t$ count $(3.739)>t$ table (1.66). The average difference was 9.59 .
\end{abstract}

Keywords: critical thinking ability, pedagogic competence, mathematics learning

\section{Abstrak}

Penelitian ini bertujuan untuk menganalisis perbedaan antara kemampuan berpikir kritis siswa yang dididik oleh guru berkompetensi pedagogik tinggi dan pedagogik rendah pada pembelajaran matematika tentang volume bangun ruang di kelas $\mathrm{V}$ SDN se-Kecamatan Alian tahun ajaran 2020/2021. Penelitian ini menggunakan pendekatan kuantitatif dengan metode penelitian komparasi. Populasi penelitian ini adalah 35 guru dan 847 siswa dengan jumlah sampel 17 guru dan 162 siswa kelas V SDN se-Kecamatan Alian. Teknik pengumpulan data menggunakan teknik tes. Analisis data menggunakan independent sample t-test. Hasil penelitian menunjukkan bahwa terdapat perbedaan kemampuan berpikir kritis siswa yang dididik oleh guru berkompetensi pedagogik tinggi dan pedagogik rendah. Hal ini dapat ditunjukkan dari nilai Sig. 0,000 $<0,05$ dan thitung $(3,739)>$ tabel $(1,66)$. Rata-rata kemampuan berpikir kritis siswa yang dididik oleh guru berkompetensi pedagogik tinggi yaitu 68,49 dan pedagogik rendah yaitu 58,90 , sehingga kompetensi pedagogik guru yang tinggi memberikan pengaruh lebih baik terhadap kemampuan berpikir kritis siswa.

Kata kunci: kemampuan berpikir kritis, kompetensi pedagogik, pembelajaran matematika 


\section{PENDAHULUAN}

Guru merupakan komponen yang berpengaruh terhadap terciptanya proses dan hasil pendidikan yang berkualitas. Guru sebagai pendidik di sekolah memiliki tanggung jawab dalam mempersiapkan generasi muda yang berkualitas dan mampu menghadapi berbagai tantangan masa depan. Dalam UU No. 14 Tahun 2005 tentang Guru dan Dosen disebutkan bahwa guru adalah pendidik profesional dengan tugas utama mendidik, mengajar, membimbing, mengarahkan, melatih, menilai, dan mengevaluasi peserta didik pada pendidikan formal. Agar dapat melaksanakan tugas keprofesionalannya dengan baik, guru wajib memiliki kompetensi. Kompetensi guru meliputi kompetensi pedagogik, kompetensi kepribadian, kompetensi sosial, dan kompetensi profesional.

Kompetensi pedagogik penting dimiliki dan diterapkan guru dalam pembelajaran Hal ini sesuai pendapat Karea (2020: 851), "Pedagogic competencies include things that are very important in learning such as teaching skills, evaluation, and assesment". Maksud dari pendapat tersebut adalah kompetensi pedagogik termasuk hal yang sangat penting di dalam pembelajaran meliputi keterampilan mengajar, mengevaluasi, dan asesmen. Mulyasa (2009) mendefinisikan kompetensi pedagogik sebagai kemampuan guru dalam mengelola pembelajaran yang meliputi pemahaman terhadap peserta didik, perancangan dan pelaksanaan pembelajaran, evaluasi hasil belajar, dan pengembangan potensi peserta didik.

Berdasarkan Permendiknas No. 35 tahun 2010 tentang Petunjuk Teknis Pelaksanaan Jabatan Fungsional Guru dan Angka Kreditnya, terdapat 7 indikator kompetensi pedagogis guru yaitu: (1) menguasai karakteristik peserta didik; (2) menguasai teori belajar dan prinsip-prinsip pembelajaran yang mendidik, (3) pengembangan kurikulum, (4) kegiatan pembelajaran yang mendidik, (5) pengembangan potensi peserta didik, (6) komunikasi dengan peserta didik, (7) penilaian dan evaluasi. Destiana dan Utami (2017: 213) menambahkan, indikator kompetensi pedagogik guru yaitu : (1) memahami konsep pendidikan, (2) memahami karakteristik peserta didik, (3) memiliki kemampuan mengelola pembelajaran khususnya pengembangan keterampilan berfikir, bekerja, dan penggunaan teknologi di abad 21.

Berdasarkan uraian di atas, indikator yang akan digunakan untuk mengukur kompetensi pedagogik guru dalam penelitian ini adalah (1) menguasai karakteristik peserta didik; (2) menguasai teori belajar dan prinsip-prinsip pembelajaran mendidik; (3) mengembangkan kurikulum; (4) menyelenggarakan pembelajaran yang mendidik; (5) mengembangkan potensi peserta didik; (6) berkomunikasi dengan peserta didik; (7) mengevaluasi pembelajaran.

Berdasarkan hasil wawancara dengan wali kelas V di SD Negeri Karangtanjung ditemukan bahwa guru masih minim dalam memahami teori belajar maupun berbagai model dan metode yang tepat dalam pembelajaran. Teknologi informasi dan komunikasi yang dapat menunjang pembelajaran juga masih belum digunakan secara efektif dalam pembelajaran. Sementara itu, dari hasil wawancara dengan wali kelas $\mathrm{V}$ di SD Negeri 2 Bojongsari menunjukkan bahwa guru sudah menggunakan teknologi informasi dan komunikasi yang bervariasi dalam pembelajaran jarak jauh. Berbagai metode pembelajaran mendidik dan menarik juga diterapkan dalam pembelajaran jarak jauh seperti penugasan individu dan kelompok, dan demonstrasi. Hal tersebut menunjukkan bahwa kompetensi pedagogik guru antara satu sekolah dengan sekolah lainnya berbeda.

Pelaksanaan pembelajaran abad 21 saat ini berorientasi pada keterampilan berpikir tingkat tinggi atau High Order Thinking Skills (HOTS) (Ariyana, dkk., 2018). Salah satu keterampilan tersebut adalah berpikir kritis atau critical thinking. Hal ini sesuai dengan Permendikbud No. 20 tahun 2016 yang tertulis bahwa berpikir kritis 
menjadi salah satu standar kelulusan bagi siswa sekolah dasar, sehingga diharapkan lulusan sekolah dasar memiliki keterampilan berpikir dan bertindak secara kreatif, produktif, kritis, mandiri, kolaboratif, dan komunikatif. Berpikir kritis didefinisikan oleh Ennis (Haeruman, Rahayu, dan Ambarwati, 2017) sebagai berikut, "critical thingking is reasonable, reflective thinking that is focused on deciding what to believe and do" yang artinya berpikir kritis adalah berpikir dengan didasari alasan dan reflektif yang berfokus pada pembuatan keputusan tentang apa yang harus diyakini dan apa yang harus dipercayai. Kemampuan berpikir kritis adalah proses kognitif siswa dalam menganalisis masalah secara sistematis dan spesifik, membedakan masalah dengan cermat dan teliti serta mengidentifikasi dan mengkaji informasi guna merencakan strategi pemecahan masalah (Azizah, Sulianto, dan Cintang, 2018). Kemampuan berpikir kritis penting untuk diterapkan dalam pembelajaran matematika agar siswa dapat mempraktekkan dan mentransfer pemahamannya dalam kehidupan sehari-hari, karena pembelajaran matematika tidak akan bermakna apabila tidak diimplementasikan dalam kehidupan nyata (Azizah, Sulianto, dan Cintang, 2018). Indikator kemampuan berpikir kritis yaitu (1) interpretation, (2) analisis, (3) inference, (4) evaluation, (5) explanation, dan (6) self-regulation (Facione, 2016). Sementara itu, menurut Farhana dan Hamdu (2016), indikator kemampuan berpiki kritis yaitu (1) klarifikasi dasar, (2) menentukan kesimpulan, (3) menentukan strategi dan taktik. Facione (Pratiwi, Mirza, dan Nursangaji, 2016) menuturkan bahwa seseorang dikatakan berpikir kritis tidak harus memenuhi semua indikator kemampuan berpikir kritis. Oleh karena itu, penelitian ini berfokus pada indikator menganalisis dan menginferensi.

Hasil observasi yang dilaksanakan di SD Negeri Karangtanjung menunjukkan bahwa kemampuan berpikir kritis belum begitu dikembangkan guru dalam pembelajaran, terutama pembelajaran matematika. Hal tersebut terlihat dari sejumlah $65 \%$ siswa di kelas tersebut masih kesulitan siswa dalam menghubungkan soal cerita ke dalam konsep volume bangun ruang yaitu balok dan kubus. Misalnya masih kesulitan dalam menentukan tinggi air dalam wadah yang direbahkan, ketika diketahui tinggi air ketika dalam wadah yang berdiri. Siswa lebih memahami volume balok dan kubus dengan rumus, bukan pada konsep volume. Memang terbatasnya ruang dan waktu saat pembelajaran jarak jauh saat ini menjadikan guru hanya menekankan rumus-rumus dan menghitung volume kubus dan balok secara sederhana, padahal matematika itu harus mengembangkan logika, reasoning, dan beragumentasi. Hal ini mengakibatkan konsep volume bangun ruang kurang tertanam dengan baik dalam pemikiran siswa.

Kemampuan berpikir kritis siswa akan berbeda jika dididik oleh guru yang berkompetensi pedagogik tinggi dengan guru yang berkompetensi pedagogik rendah. Guru yang memiliki kompetensi pedagogik yang baik maka dapat mengembangkan cara berpikir dan kreativitas siswanya (Oser dan Calkers dalam Adegbola dan Florence, 2019). Oleh karena itu, siswa akan memiliki kemampuan berpikir kritis yang tinggi jika dididik oleh guru berkompetensi pedagogik tinggi.

Berdasarkan pemaparan di atas, peneliti tertarik melakukan penelitian untuk menganalisis perbedaan pengaruh kompetensi pedagogik guru terhadap kemampuan berpikir kritis siswa dengan judul "Perbedaan Pengaruh Kompetensi Pedagogik Guru terhadap Kemampuan Berpikir Kritis Siswa pada Pembelajaran Matematika tentang Volume Bangun Ruang di Kelas V SD Negeri Se-Kecamatan Alian Tahun Ajaran 2020/2021". Tujuan penelitian ini adalah menganalisis perbedaan kemampuan berpikir kritis siswa yang dididik oleh guru berkompetensi pedagogik tinggi dan pedagogik rendah pada pembelajaran matematika tentang volume bangun ruang di kelas V SD Negeri se-Kecamatan Alian tahun ajaran 2020/2021.

\section{METODE}


Penelitian ini menggunakan pendekatan penelitian kuantitatif dengan metode penelitian komparasi. Populasi penelitian ini semua guru dan siswa kelas V SD Negeri se-Kecamatan Alian berjumlah 35 guru dan 847 siswa. Adapun teknik pengambilan sampel penelitian ini adalah purposif sampling. Guru yang dijadikan sampel dalam penelitian ini memiliki kriteria: (1) PNS, (2) berumur 30-50 tahun, dan (3) minimal lulusan S-1 pendidikan. Sedangkan siswa yang dijadikan sampel dalam penelitian ini adalah siswa dari guru yang berkompetensi pedagogik tingi dan rendah. Oleh karena itu, sampel penelitian ini yaitu 17 guru dan 162 siswa kelas V SDN se-Kecamatan Alian. Teknik pengumpulan data yang digunakan dalam penelitian ini adalah teknik tes. Tes yang digunakan untuk mengukur tingkat kompetensi pedagogik guru adalah tes objektif dengan indikator: (1) menguasai karakteristik peserta didik, (2) menguasai teori belajar dan prinsip-prinsip pembelajaran mendidik, (3) mengembangkan kurikulum, (4) menyelenggarakan pembelajaran yang mendidik, (5) mengembangkan potensi peserta didik, (6) berkomunikasi dengan peserta didik, dan (7) mengevaluasi pembelajaran, sedangkan tes yang digunakan untuk mengukur kemampuan berpikir kritis siswa adalah tes uraian tentang volume bangun ruang (kubus dan balok) dengan indikator menganalisis dan menginferensi. Uji prasyarat data penelitian ini yaitu uji normalitas dan uji homogenitas. Teknis analisis data menggunakan independent sample t-test.

\section{HASIL DAN PEMBAHASAN}

Instrumen yang digunakan untuk mengetahui tingkat kompetensi pedagogik guru adalah tes objektif berjumlah 32 butir yang dikembangkan dari 7 indikator kompetensi pedagogik guru. Tes tersebut diberikan kepada 17 guru di Kecamatan Alian yang menjadi sampel penelitian untuk diteliti tingkat kompetensi pedagogik masing-masing guru. Hasil tes dibagi menjadi 3 kelompok yaitu guru berkompetensi pedagogik tinggi, sedang, dan rendah. Pembagian kelompok ini diawali dengan mengurutkan perolehan skor total tes kompetensi guru, lalu ditentukan $27 \%$ guru dengan skor tertinggi sebagai guru berkompetensi pedagogik tinggi, dan $27 \%$ guru dengan skor terendah sebagai guru berkompetensi pedagogik rendah.

Tabel 1. Distribusi Frekuensi Tes Kompetensi Pedagogik Guru

\begin{tabular}{cc}
\hline Aspek & Frekuensi \\
\hline $27-28$ & 2 \\
$25-26$ & 5 \\
$23-24$ & 2 \\
$21-22$ & 4 \\
$19-20$ & 4 \\
Jumlah & 17 \\
\hline
\end{tabular}

Berdasarkan tabel di atas, 27\% dari 17 adalah 4, sehingga dari 17 guru yang telah menyelesaikan tes kompetensi pedagogik guru, didapatkan 4 guru berkompetensi pedagogik tinggi dan 4 guru berkompetensi pedagogik rendah. Selanjutnya, siswa dari guru yang berkompetensi pedagogik tinggi dan rendah diteliti tingkat kemampuan berpikir kritisnya.

Tabel 2. Distribusi Frekuensi Tes Kemampuan Berpikir Kritis Siswa

\begin{tabular}{cccc}
\hline \multicolumn{2}{c}{ Kelompok Atas } & \multicolumn{2}{c}{ Kelompok Bawah } \\
\hline Interval & Frekuensi & Interval & Frekuensi \\
$92-100$ & 3 & $92-100$ & 3 \\
$83-91$ & 9 & $83-91$ & 4 \\
$74-82$ & 20 & $74-82$ & 11 \\
$65-73$ & 19 & $65-73$ & 14 \\
$56-64$ & 16 & $56-64$ & 19 \\
$47-55$ & 6 & $47-55$ & 10
\end{tabular}




\begin{tabular}{cccc}
$38-46$ & 5 & $38-46$ & 11 \\
$29-37$ & 2 & $29-37$ & 5 \\
$20-28$ & 0 & $20-28$ & 5 \\
Jumlah & 80 & Jumlah & 82 \\
\hline
\end{tabular}

Sebelum data diolah lebih lanjut dilakukan uji prasyarat analisis data. Dalam penelitian dilakukan uji normalitas dan homogenitas. Uji normalitas yang digunakan dalam penelitian ini menggunakan uji kolmogorov-smirnov, sedangkan uji homogenitasnya menggunakan uji Levene.

Tabel 3. Uji Normalitas dan Homogenitas Kemampuan Berpikir Kritis

\begin{tabular}{lcccccc}
\hline & \multirow{2}{*}{ Kompetensi } & \multicolumn{3}{c}{ Kolmogorov-smirnov } & \multicolumn{2}{c}{ Levene } \\
& Pedatistic \\
& & Statistic & df & Sig. & $F$ & Sig. \\
\hline Kemampuan berpikir kritis & Tinggi &, 070 & 80 &, 200 & 3,362 & \multirow{2}{*}{069} \\
siswa & Rendah &, 057 & 82 &, 200 & 3,30 \\
\hline
\end{tabular}

Dari tabel 3 pada kolom kolmogorov-smirnov didapatkan nilai signifikansi (Sig.) 0,200 untuk data kemampuan berpikir kritis siswa yang dididik oleh guru berkompetensi pedagogik tinggi, dan 0,200 untuk data kemampuan berpikir kritis siswa yang dididik oleh guru berkompetensi pedagogik rendah. Nilai 0,200 lebih besar dari 0,05 , sehingga kedua data tersebut berdistribusi normal.

Pada tabel 3 kolom Levene statistic didapatkan nilai Sig. sebesar 0,069. Nilai tersebut lebih dari 0,05 , sehingga data kemampuan berpikir kritis siswa pada penelitian ini memiliki varian data yang homogen.

Tabel 4. Hasil Analisis Uji Perbandingan Kemampuan Berpikir Kritis dengan Independent Sample T-Test

\begin{tabular}{llllc}
\hline & $\begin{array}{c}\text { Kompetensi } \\
\text { Pedagogik } \\
\text { Guru }\end{array}$ & N & Mean & $\begin{array}{c}\text { Std. } \\
\text { Deviation }\end{array}$ \\
\hline Kemampuan Berpikir Kritis & tinggi & 80 & 68,49 & 14,658 \\
Siswa & rendah & 82 & 58,90 & 17,781 \\
\hline
\end{tabular}

Dari tabel di atas diperoleh nilai rata-rata kemampuan berpikir kritis dari guru berkompetensi pedagogik tinggi dan rendah. Siswa yang yang dididik oleh guru berkompetensi pedagogik tinggi berjumlah 80 siswa, sedangkan siswa yang dididik oleh guru berkompetensi pedagogik rendah berjumlah 82 siswa. Rata-rata kemampuan berpikir kritis siswa kelas $\mathrm{V}$ yang dididik oleh guru berkompetensi pedagogik tinggi adalah 68,49 , sedangkan rata-rata kemampuan berpikir kritis siswa kelas $\mathrm{V}$ yang dididik oleh guru berkompetensi pedagogik rendah adalah 58,90.

Tabel 5. Hasil Analisis Uji Perbedaan Kemampuan Berpikir Kritis dengan Independent Sample T-Test

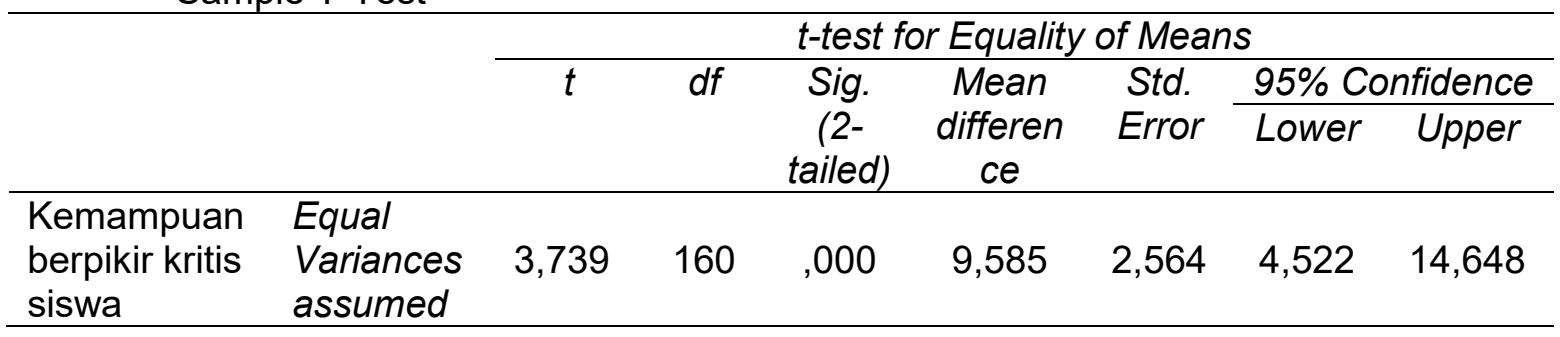

Dari output di atas, didapatkan nilai signifikansi (Sig. 2-tailed) sebesar 0,000, sehingga dapat dinyatakan bahwa $0,000<0,05$. Karena signifikansi kurang dari 0,05 maka kesimpulannya adalah terdapat perbedaan kemampuan berpikir kritis siswa yang 
dididik oleh guru berkompetensi pedagogik tinggi dan kemampuan berpikir kritis siswa yang dididik oleh guru berkompetensi pedagogik rendah serta kompetensi pedagogik guru yang tinggi memberikan pengaruh yang lebih baik terhadap kemampuan berpikir kritis siswa.

Berdasarkan output tersebut juga didapatkan t hitung sebesar 3,739. Selanjutnya nilai tersebut dibandingkan dengan nilai t tabel dengan df 160 . $T$ tabel dengan $\mathrm{df}=160$ dan taraf kesalahan $5 \%$ memiliki nilai 1,66 . Hasil t hitung $(2,919)>t$ tabel $(1,66)$. Hasil ini menunjukkan bahwa kemampuan berpikir kritis siswa yang dididik oleh guru berkompetensi pedagogik tinggi dan guru berkompetensi pedagogik rendah Kelas $\mathrm{V}$ SD Negeri se-Kecamatan Alian adalah signifikan dan dapat diberlakukan untuk populasi.

Pada output pertama, rata-rata kemampuan berpikir kritis siswa yang dididik oleh guru berkompetensi pedagogik tinggi adalah 68,49, sedangkan kemampuan berpikir kritis siswa yang dididik oleh guru berkompetensi pedagogik rendah adalah 58,90. Selisih rata-rata kemampuan berpikir kritis siswa yang dididik oleh guru berkompetensi pedagogik tinggi dan rendah adalah 9,59.

Dari hasil analisis tersebut dapat disimpulkan bahwa kompetensi pedagogik guru yang tinggi memberikan pengaruh lebih baik terhadap kemampuan berpikir kritis siswa. Hasil penelitian ini sesuai dengan pendapat Faltis, Christian, dan Abdei (Susanto, Rozali, dan Agustina, 2019) bahwa kompetensi pedagogik guru memberikan pengaruh yang signifikan terhadap hasil belajar siswa. Pendapat ini diperkuat oleh pendapat Oser dan Calkers (Adegbola dan Florence, 2019) yang mengatakan bahwa guru yang memiliki kompetensi pedagogik yang baik akan dapat mengembangkan cara berpikir dan kreativitas siswanya. Senada dengan hal tersebut, Senturk dan Zeybek (2019: 67) mengatakan bahwa guru yang memiliki pemahaman pedagogik tinggi akan dapat melaksanakan pembelajaran yang kreatif dan mengatasi kesulitan yang dialami siswa. Dengan mengembangkan kompetensi pedagogik guru dalam pembelajaran maka guru dapat melakukan penyesuaian dengan mudah pada situasi yang berbeda (From: 2017: 44). Hasil penelitian ini juga menguatkan penelitian yang dilakukan oleh Serviana (2020) yaitu kompetensi pedagogik guru berpengaruh signifikan terhadap kemampuan berpikir kritis siswa pada pembelajaran Sejarah Kebudayaan Islam di MI Muhammadiyah Bae. Oleh karena itu, semakin tinggi kompetensi pedagogik guru, semakin baik pula kemampuan berpikir kritis siswanya.

\section{SIMPULAN}

Berdasarkan hasil penelitian diperoleh simpulan bahwa ada perbedaan pengaruh kompetensi pedagogik guru terhadap kemampuan berpikir kritis siswa pada pembelajaran matematika tentang volume bangun ruang di kelas V SD Negeri seKecamatan Alian tahun ajaran 2020/2021. Hal tersebut ditunjukkan dengan nilai Sig. pada uji Independent sample t-test yaitu 0,000 yang berarti bahwa nilai 0,000<0,05 (taraf kesalahan $5 \%$ ) sehingga tolak $\mathrm{H}_{0}$. Rata-rata kemampuan berpikir kritis siswa yang dididik oleh guru berkompetensi pedagogik tinggi yaitu 68,49, sedangkan ratarata kemampuan berpikir kritis siswa yang dididik oleh guru berkompetensi pedagogik rendah yaitu 58,90. Implikasi pada penelitian ini adalah kompetensi pedagogik guru yang tinggi memberikan pengaruh yang lebih baik terhadap kemampuan berpikir kritis siswa. Upaya yang dapat dilakukan guru untuk meningkatkan kompetensi pedagogiknya yaitu dengan mengikuti berbagai diklat atau webinar tentang strategi pembelajaran HOTs, sedangkan untuk meningkatkan kemampuan berpikir kritis siswa dalam pembelajaran dapat dilakukan dengan menggunakan model pembelajaran cooperative script, project based learning dan model pembelajaran lainnya. 


\section{DAFTAR PUSTAKA}

Adegbola dan Florence, F. (2019). Teachers' Pedagogical Competence as Determinants of Students' Attitude Towards Basic Science in South West Nigeria. Academic Journal, 14(18), 655-660.

Arikunto, S. (2013). Prosedur Penelitian: Suatu Pendekatan. Jakarta: Rineka Cipta.

Ariyana, dkk. (2018). Buku Pegangan Pembelajaran Berorientasi pada Keterampilan Berpikir Tingkat Tinggi: Direktorat Jenderal Guru dan Tenaga Kependidikan Kementrian Pendidikan dan Kebudayaan.

Azizah, M., Sulianto, J., \& Cintang, N. (2018). Analisis Keterampilan Berpikir Kritis Siswa Sekolah Dasar pada Pembelajaran Matematika Kurikulum 2013. Jurnal Penelitian Pendidikan, 35(1), 61-70.

Facione, P. (2016). Think Critically. United States of America: Pearson.

Farhana, H.O.H.P. dan Hamdu, G. (2016). Penerapan Strategi Pemecahan Masalah dalam Peningkatan Kemampuan Berpikir Kritis Siswa pada Pembagian Pecahan. Pedadidaktika Jurnal IImiah Mahasiswa Pendidikan Guru Sekolah Dasar, 3(2), 303-321.

From, J. (2017). Pedagogical Digital Competence-Between Values, Knowledge and Skill. Higher Education Studies, 7(2), 43-50.

Haeruman, L.D., Rahayu, W., \& Ambarwati, L. (2017). Pengaruh Model Discovery Learning terhadap Peningkatan Kemampuan Berpikir Kritis Matematis dan SelfConfidence Ditinjau dari Kemampuan Awal Matematis Siswa SMA di Bogor Timur:

Karea, S. (2020). Pedagogic Competence and Indonesian Language Competence PreService Teacher of Elemantary Program. International Journal of Scientic \& Technology Research, 8 (10), 851-856.

Kementrian Pendidikan dan Kebudayaan RI. (2010). Peraturan Mendiknas tentang Petunjuk Teknis Pelaksanaan Jabatan Fungsional Guru dan Angka Kreditnya. (Permendikbud No. 35 tahun 2010). Jakarta: Penulis.

Kementrian Pendidikan dan Kebudayaan RI. (2010). Peraturan Mendiknas tentang Standar Kompetensi Lulusan Pendidikan Dasar dan Menengah. (Permendikbud No. 20 tahun 2016). Jakarta: Penulis.

Mulyasa, E. (2009). Standar Kompetensi dan Sertifikasi Guru. Bandung: PT Remaja Rosdakarya.

Pratiwi, J.A., Mirza A., dan Nursangaji, A. (2016). Kemampuan Berpikir Kritis Aspek Analysis Siswa di Sekolah Menengah Atas: Jurnal Pendidikan dan Pembelajaran Khatulistiwa, 5(12), 1-12.

Senturk, C., dan Zeybek, G. (2019). Teacher Learning Conceptions and Pedagogical Competence Perceptions of Teachers: A Correlational Research. Research in Pedagogy, 9(1), 65-80

Serviana, D. (2020). Pengaruh Kompetensi Pedagogik Guru terhadap Kemampuan Berpikir Kritis Siswa pada Pembelajaran Sejarah Kebudayaan Islam Kelas IV di MI Muhammadiyah Bae Kudus Tahun Pelajaran 2019/2020. Skripsi Dipublikasikan. Fakultas Taribiyah IAIN Kudus.

Supriyono, A. (2017). Pengaruh Kompetensi Pedagogik, Profesional, dan Motivasi Kerja terhadap Kinerja Guru Sekolah Dasar. Jurnal Pendidikan, 18(2), 1-12.

Susanto, R., Rozali, Y.A., \& Agustina, N. (2019). Development of Pedagogical Competency Models for Elemantary School Teachers: Pedagogical Knowledge, Reflective Ability, Emotional Intelligence and Instructional Communication Pattern. Universal Journal of Educational Research, 7 (10), 2124-2032.

Undang-Undang Nomor 14 tahun 2005 tentang Guru dan Dosen.

Undang-Undang Nomor 16 tahun 2007 tentang Standar Kualifikasi Akademik dan Kompetensi Guru. 